\title{
Research Note: Field Trial on the Effects of Homemade Probiotics and Sweet Potato Silage Supplementation on Sows Productivity and Profitability in the Marginal Upland Area in Inopacan, Leyte
}

\author{
Julius V. Abela, Alberto A. Taveros and Bryan Rebuyas
}

Department of Animal Science, Visayas State University, Baybay City, Leyte

\begin{abstract}
This study is part of the big CHED-Phernet program on "Enhancing Farm Productivity and Environmental Quality in Climate Change Vulnerable Marginal Uplands of Eastern Visayas. An incomplete randomized block design was used in control field trial was conducted from May 2013 to December 2013 involving 9 sows in Guinsangaan, Linao, and Marao Inopacan, Leyte. Homemade liquid probiotics and sweet potato silage were given to the treatment group. The sows performance on the average littersize born/Average littersize at weaning for $\mathrm{T}_{0}$ (commercial feeds) was $9.33 / 6.33$ hds., while $\mathrm{T}_{1}$ (commercial feeds $+20 \mathrm{ml} \mathrm{HMP}$ ) was 11.0/10.33 hds, and $\mathrm{T}_{2}$ (commercial feeds + $20 \mathrm{ml} \mathrm{HMP} \mathrm{+} \mathrm{crop-silage} \mathrm{by-products} \mathrm{@} \mathrm{0.10 \%} \mathrm{BW} \mathrm{on}$ DM basis) $9.67 / 8.67 \mathrm{hds}$, and the average weaning weight for $\mathrm{T}_{0}=8.61 \mathrm{~kg}, \mathrm{~T}_{1}=$ $9.23 \mathrm{kgs}$, and $\mathrm{T}_{2}=8.35 \mathrm{kgs}$, respectively. However, the total number of weaned piglets for each treatment resulted to a significant profitability (given the price per weanling equivalent to Php 2,000 per head) of the treatment assigned to sows productivity performance based on these results $\mathrm{T}_{0}=19 \mathrm{hds}$ (Php 38,000.00), $\mathrm{T}_{1}=31$ hds (Php 62,000.00), and $\mathrm{T}_{2}=26$ hds (Php $48,000.00)$. The introduction of crop-silage plus HMP technology increases the productivity of the sows and likewise, increases the profitability in terms of peso income after weaning the piglets of marginal upland area pig raisers.
\end{abstract}

Keywords: $\quad$ Crop-Silage - this is a by-product of sweet potato matured vines/remains after harvesting the rootcrop. The SPMV was subjected to fermentation process called Silage.

Correspondence : A.A. Taveros Address: Department of Animal Science, Visayas State University, Visca Baybay City, Leyte Email: ataveros@yahoo.com DOI: 10.32945/atr36s13.2014 


\section{INTRODUCTION}

The importance of pork to Philippine food security on protein requirements to young individuals affected several government and nongovernment researches. A review of such revealed that a significant number focused on nutrition and reproduction because improving them has been shown to increase the profitability and sustainability of the production system.

Marginal upland areas in Region 8 (Eastern Visayas) are quite many and are characterized by its shallow soil fertility, inability to hold water because of slope and terrain, and inferior quality of existing vegetation, which limit productivity, both in crops and livestock. The more common species of livestock raised include: native chickens, pigs and small ruminants (mainly goats). Although livestock production depends on crops being grown, livestock acts as "shock absorber" of the impact of fluctuating prices and productivity of crops. In the advent of changing weather conditions, uplifting livestock production in the marginal uplands must be given impetus. Pig production especially raising sows is really a big help in terms of income if the appropriate technology can improve the poor production of sows in marginal areas.

In Region VIII from 1991 to 2002, hog-raising has consistently been the top livestock activity (NSO, 2004). This is due to the fact that pork is the most preferred animal meat (Argañoza, 1989). In the Philippines, average per capita consumption increased from 13.26 kilograms in 1990 to 16.09 kilograms in 2000,16.88 kg in 2002 (PCARRD, 2006), and $18.62 \mathrm{~kg}$ in 2007 (The PigSite, 2009).

Probiotic products for various livestock production systems thus came into the picture mostly as feed supplement and in swine, mostly for piglets. Just like antibiotics, the primary reason for their use is to improve intestinal health by modifying the composition of the resident intestinal microbes. It is a well-established fact that the health of the gastrointestinal tract generally affects the health of the animal. Several studies have already been conducted to determine the effect of dietary supplementation with probiotics in swine and other livestock species. Lactobacillus species were used while others, yeast cells were used. Further, other studies used the above microorganisms alone or in combination with other ingredients including probiotics, enzymes or herbal extracts.

To broaden the range of validity of the conclusions beyond the confines of the researcher and to facilitate adoption of this study by appropriate 
farmers was justified by the results of this study included in the three selected barangays pig farm raisers raising cross breeds and varying in management practices in different geographical locations.

\section{Objectives of the Study}

Specifically, this aimed to compare:

1. Litter performance in terms of the following:

a. Litter size at birth born alive (LSBBA) and at weaning (LSW);

b. Litter weight at birth (LWB) and at weaning (LWW); and

c. Pre-weaning mortality (PWM); and,

2. Benefits of Homemade Probiotics and Crop-silage byproduct of Sweet Potato Mature Vines in marginal upland pig raisers.

\section{METHODOLOGY}

The enrolment of the farm and their sows for this study was purposive using the following criteria:

1. The trial had at least 9 sows around 3-5 parity with three (3) sows were bred around May to July $2013\left(\mathrm{~T}_{0}\right)$, three (3) sows were bred in June to July $2013\left(\mathrm{~T}_{1}\right)$ and the other three (3) sows $\left(\mathrm{T}_{2}\right)$ in March, June and July 2013;

2. The farm owner agreed to use the newly introduced HMP and cropsilage technology starting on the day feeding trial until weaning day of the piglets.

3. The sow and litter were kept in individual farrowing pens.

4. The farm followed a thirty (30) day lactation period; and,

5. The research was allowed access to farm records on the experimental animals.

Nine (1-3 years old) lactating sows were used in the study (Figure 1 and Table 1). From each of these gestating-to-weaning the sows. The three sows in each block were randomly distributed to the three treatment groups and were observed during farrow-to weaning period.

The three (3) sows in each block were randomly distributed to the three treatment groups as follows: $\mathrm{T}_{0}-$ (commercial feeds); $\mathrm{T}_{1}-$ (commercial feeds $+20 \mathrm{ml} \mathrm{HMP}$ ); and $\mathrm{T}_{2}$ - (commercial feeds $+20 \mathrm{ml} \mathrm{HMP}+$ crop-silage by-products @ 0.10\% BW on DM basis) (Figures 2-5). 


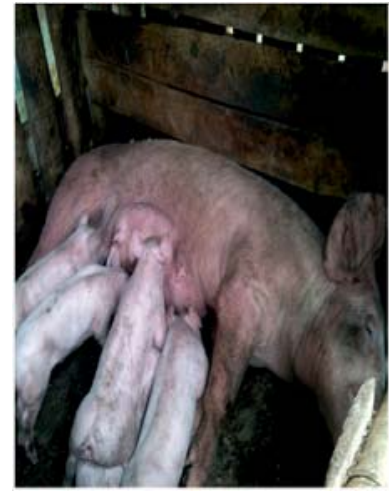

Sow No. 1, Block 1, T0

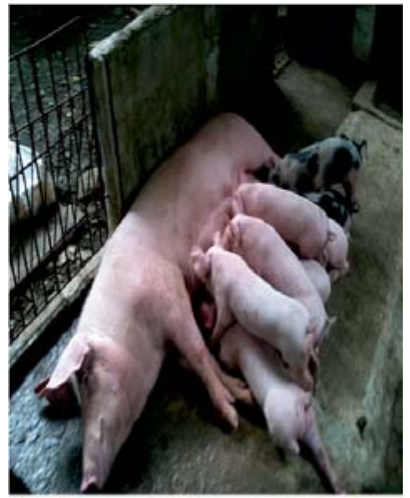

Sow No. 2, Block 1, T1

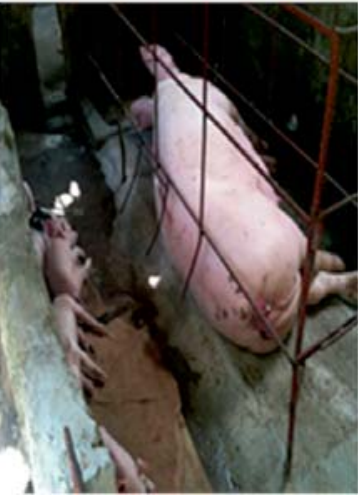

Sow No. 3, Block 1, T2

Figure 1. The sample experimental sows in the treatment

Table 1. Experimental layout showing the block allocation

\begin{tabular}{cccc}
\hline Treatments & \multicolumn{3}{c}{ For Heat Sows in Third to Fifth Parity } \\
(May to July 2013)
\end{tabular}

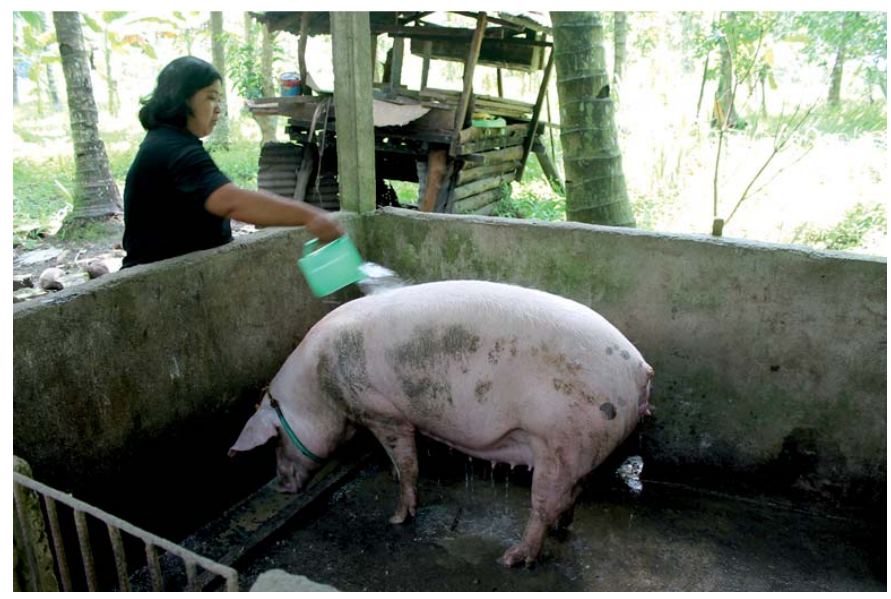

Figure 2. Commercial Feeding 
Abela et al.

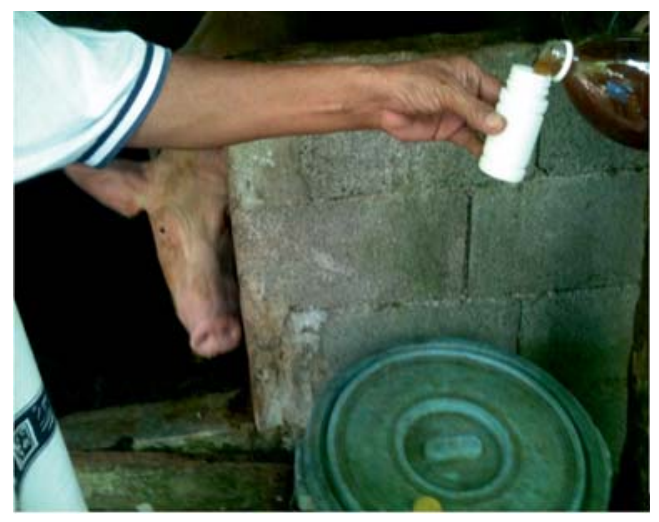

Figure 3. Commercial feeds $+20 \mathrm{ml} \mathrm{HMP}$

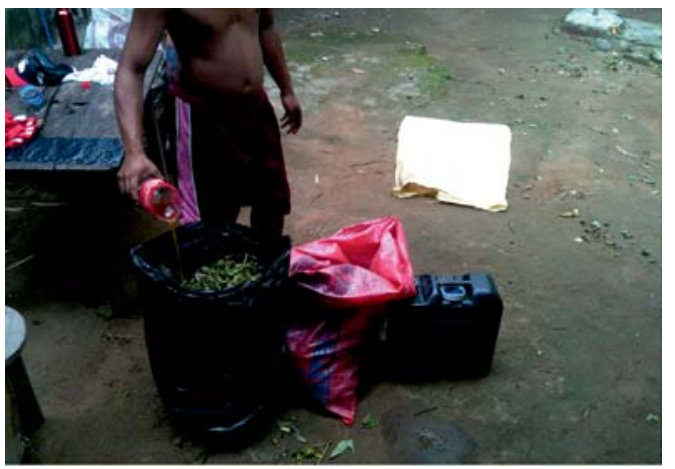

Figure 4. Commercial feeds + $20 \mathrm{ml} \mathrm{HMP} \mathrm{+} \mathrm{crop-silage} \mathrm{by-products}$

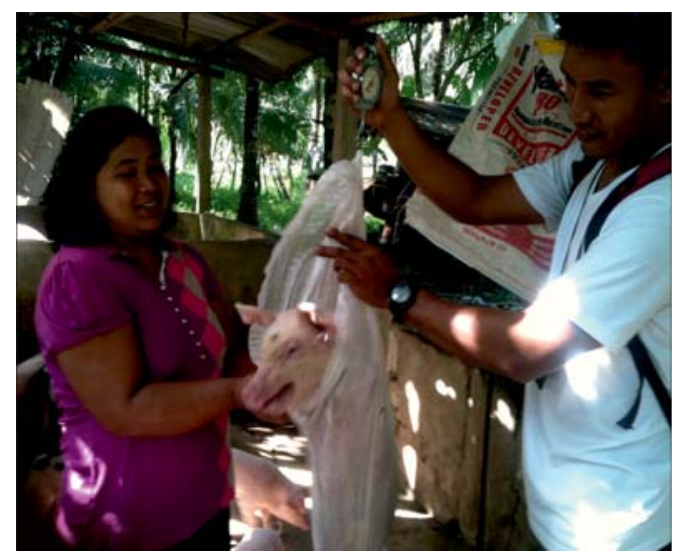

Figure 5. Weighing of 30 day old weanlers 


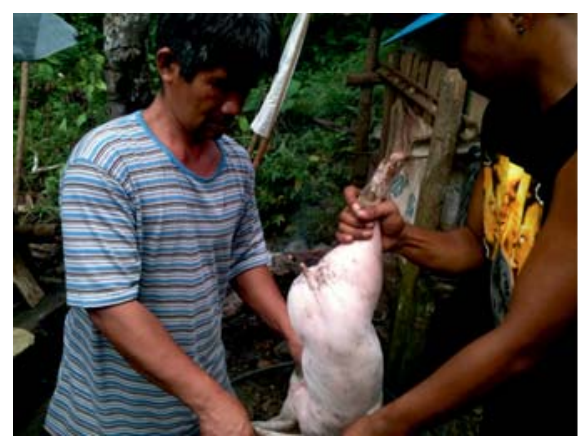

Figure 6. Harvesting weanlers

\section{RESULTS AND DISCUSSION}

\section{Litter Performance}

Results showed (Table 2) that the sows performance on the average litter size born/average litter size at weaning for $\mathrm{T}_{0}$ (commercial feeds) was 9.33/6.33 hds., while $\mathrm{T}_{1}$ (commercial feeds $+20 \mathrm{ml}$ HMP) was 11.0/10.33 hds, and $\mathrm{T}_{2}$ (commercial feeds $+20 \mathrm{ml} \mathrm{HMP}+$ crop-silage byproducts @ 0.10\% BW on DM basis) 8.67/8.22 hds, and the average weaning weight for $\mathrm{T}_{0}=8.61 \mathrm{~kg}, \mathrm{~T}_{1}=9.23 \mathrm{kgs}$, and $\mathrm{T}_{2}=8.35 \mathrm{kgs}$, respectively.

Table 2. Litter performance to sow feed with homemade probiotics and control.

\begin{tabular}{llrrrrr}
\hline \multirow{2}{*}{ Treatments } & Sows & $\begin{array}{c}\text { Litter Size } \\
\text { Born }\end{array}$ & $\begin{array}{c}\text { Litter Size } \\
\text { Born Alive }\end{array}$ & $\begin{array}{c}\text { Litter Size } \\
\text { Wean }\end{array}$ & $\begin{array}{c}\text { Weight at } \\
\text { Birth }\end{array}$ & $\begin{array}{l}\text { Weight at } \\
\text { Weaning }\end{array}$ \\
\hline Control & 1 & 10.00 & 8.00 & 8.00 & 11.50 & 70.50 \\
& 2 & 10.00 & 10.00 & 10.00 & 17.00 & 90.25 \\
& 3 & 8.00 & 1.00 & 1.00 & 2.25 & 3.00 \\
& Sum & 28.00 & 19.00 & 19.00 & 30.75 & 163.75 \\
\cline { 2 - 7 } & Mean & 9.33 & 6.33 & 6.33 & 10.25 & 8.61 \\
\hline \multirow{2}{*}{ Treatment1 } & 1 & 11.00 & 11.00 & 10.00 & 17.25 & 90.25 \\
& 2 & 8.00 & 8.00 & 8.00 & 13.75 & 77.50 \\
& 3 & 14.00 & 14.00 & 13.00 & 21.00 & 118.50 \\
& Sum & 33.00 & 33.00 & 31.00 & 52.00 & 286.25 \\
\cline { 2 - 7 } & Mean & 11.00 & 11.00 & 10.33 & 17.33 & 9.23 \\
\hline \multirow{2}{*}{ Treatment2 } & 1 & 11.00 & 11.00 & 11.00 & 16.00 & 79.75 \\
& 2 & 8.00 & 5.00 & 5.00 & 9.50 & 43.00 \\
& 3 & 10.00 & 10.00 & 8.00 & 18.00 & 77.60 \\
& Sum & 29.00 & 26.00 & 24.00 & 43.50 & 200.35 \\
\cline { 2 - 7 } & Mean & 9.67 & 8.67 & 8.00 & 14.50 & 8.35 \\
\hline
\end{tabular}


Abela et al.

However, the total number of weaned piglets for each treatment resulted to a significant profitability (given the price per weanling equivalent to Php 2,000 per head) of the treatment assigned to sows productivity performance based on these results $\mathrm{T}_{0}=19$ hds (Php 38,000.00), $\mathrm{T}_{1}=31$ hds (Php 62,000.00), and $\mathrm{T}_{2}=24$ hds (Php 48,000.00). The introduction of HMP technology and crop-silage by-products increases the productivity of the sows and likewise, increases the profitability in terms of peso income after weaning the piglets of marginal upland area pig raisers (Figure 7 and Table 3).

Table 3. Weanling performance of sow feed with homemade probiotics with income.

\begin{tabular}{cccrrrr}
\hline \multirow{2}{*}{ Treatments } & Sow & $\begin{array}{c}\text { Total } \\
\text { Number of } \\
\text { Weanlers }\end{array}$ & $\begin{array}{c}\text { Total } \\
\text { Feed Cost }\end{array}$ & Price/piglet & $\begin{array}{r}\text { Total } \\
\text { Sales }\end{array}$ & Income \\
\hline \multirow{2}{*}{ To } & 1 & 8 & $12,408.20$ & $2,000.00$ & $16,000.00$ & $3,591.80$ \\
& 2 & 10 & $13,111.50$ & $2,000.00$ & $20,000.00$ & $6,888.50$ \\
& 3 & 1 & $6,611.65$ & $2,000.00$ & $2,000.00$ & $-4,611.65$ \\
\hline Total & 3 & 19 & $32,131.35$ & $6,000.00$ & $38,000.00$ & $5,868.65$ \\
\hline & 1 & 10 & $13,111.50$ & $2,000.00$ & $20,000.00$ & $6,888.50$ \\
T1 & 2 & 8 & $12,408.20$ & $2,000.00$ & $16,000.00$ & $3,591.80$ \\
& 3 & 13 & $14,166.45$ & $2,000.00$ & $26,000.00$ & $11,833.55$ \\
\hline Total & 3 & 31 & $39,686.15$ & $6,000.00$ & $62,000.00$ & $22,313.85$ \\
\hline & 1 & 11 & $11,064.40$ & $2,000.00$ & $22,000.00$ & $10,935.60$ \\
\multicolumn{1}{c}{ T2 } & 2 & 5 & $8,954.50$ & $2,000.00$ & $10,000.00$ & $1,045.50$ \\
& 3 & 8 & $10,009.45$ & $2,000.00$ & $16,000.00$ & $5,990.55$ \\
\hline Total & 3 & 24 & $30,028.35$ & $6,000.00$ & $48,000.00$ & $17,971.65$ \\
\hline
\end{tabular}

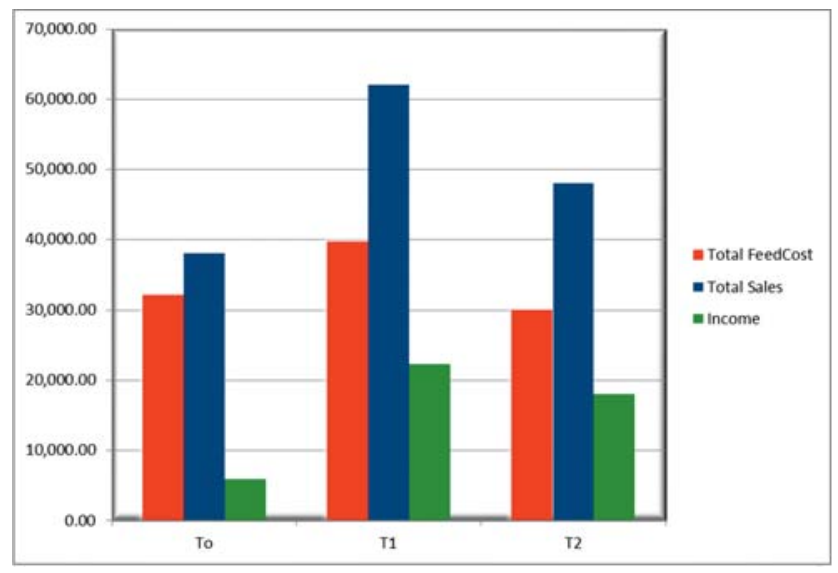

Figure 7. Performance Graph 
Homemade Probiotics and Sweet Potato Silage Supplementation

\section{REFERENCES}

ARGAÑOZA, V. 1989. Pork Production Manual. Published by: Inphilco, Philippines.

KNOX, R.V. 2000. Artificial Insemination of Swine: Improving Reproductive Efficiency of the Breeding Herd. http://www.gov.mb.ca/agriculture /livestock/pork/pdf/bab13s04.pdf (Date of publication was not indicated but literatures used include a number dated 2000.)

LAPUS, Z.M. 2009. Swine production in the Philippines (What the Experts Say). http://www.pig333.com/what_the_experts_say /pig_article/1489/swine-production-in-the-philippines-2/2-

NATIONAL STATISTICS OFFICE. 2004. A Review of the Agriculture Sector in Eastern Visayas. Retrieved on Oct. 3, 2006 from the World Wide Web: http://www.census.gov.ph/data/sectordata /sr04126tx.html

PCARRD. 2006. Swine Information Network. Retrieved on Aug. 29, 2006 from the World Wide Web: http://www.pcarrd.dost.gov.ph/cin /SWIN/status.htm

TAVEROS, A.A. and S. MORE. 2005. Field Trial on Sow Productivity. Preventive Veterinary Medicine. 46 (4-5) pp.135-148.

ThE PIGSITE. 2009 . Porcine Stress Syndrome (PSS). http://www.thepigsite.com/diseaseinfo/89/porcine-stresssyndrome-pss 